\title{
Vibrio sinaloensis sp. nov., isolated from the spotted rose snapper, Lutjanus guttatus Steindachner, 1869
}

Correspondence Bruno Gomez-Gil bruno@ciad.mx

\author{
Bruno Gomez-Gil, ${ }^{1}$ Emma Fajer-Avila, ${ }^{1}$ Javier Pascual, ${ }^{2,3}$ \\ M. Carmen Macián, ${ }^{3,4}$ María J. Pujalte, ${ }^{2,3}$ Esperanza Garay ${ }^{2,3,4}$ \\ and Ana Roque ${ }^{5}$ \\ ${ }^{1}$ CIAD, A.C., Mazatlán Unit for Aquaculture, AP. 711 Mazatlán, Sinaloa 82000, Mexico \\ ${ }^{2}$ Instituto Cavanilles de Biodiversidad y Biología Evolutiva, Universitat de València, Spain \\ ${ }^{3}$ Departamento de Microbiología y Ecología, Universitat de València, Spain \\ ${ }^{4}$ Colección Española de Cultivos Tipo (CECT), Universitat de València, Spain \\ ${ }^{5}$ Institut de Reçerca i Tecnologia Agroalimentaries, Centre d'Aquicultura, AP 200 Sant Carles de la \\ Rapita 43540, Spain
}

Many species of the genus Vibrio have been described in recent years, especially since molecular fingerprinting methods that interrogate the bacterial genome have been available. There are now over 70 species in the genus (Euzéby, 1997; last full update 4 October 2007), many isolated from cultured marine organisms. Vibrios can cause severe infections in humans and in many marine organisms, but also are considered to be part of the normal microbiota of marine invertebrates and fish (Thompson et al., 2004; Gomez-Gil et al., 2007). Most of the pathogenic vibrios studied are of an opportunistic nature, causing disease only when the health status of the host is compromised (Lightner \& Redman, 1998). Variations in virulence between strains of the same Vibrio species are a common phenomenon (Soto-Rodriguez et al., 2003) but, perhaps, pathogenic strains are the exception rather than

The GenBank/EMBL/DDBJ accession numbers for the $16 \mathrm{~S}$ rRNA gene sequences of strains CAIM 695, CAIM $797^{\top}$, CAIM 798, CAIM 752, CAIM 648 and CAIM 636 are respectively DQ451210, DQ451211 and EU043379-EU043382. the rule. Therefore, it is important to know the normal Vibrio microbiota of a cultured marine organism in order to understand better the involvement of a certain bacterial strain or species in a pathogenic process.

Nine bacterial strains were isolated on TCBS agar during November 2003 from cultured rose snappers (Lutjanus guttatus) kept at the Research Centre for Nutrition and Development (CIAD) in Mazatlán, Sinaloa state, Mexico, and they were tentatively called 'Vibrio sp. nov. 3' (cluster number 2; Gomez-Gil et al., 2007). Two strains were obtained from the liver (CAIM 648 and CAIM 694), three from the spleen (CAIM 695, CAIM 792 and CAIM $797^{\mathrm{T}}$ ), one from the kidney (CAIM 752) and three from external lesions (CAIM 750, CAIM 793 and CAIM 798), each from a different fish. The strains were deposited at the Collection of Aquatic Important Microorganisms (http://www.ciad. $\mathrm{mx} /$ caim).

As recommended by Figueras et al. (2006), these nine strains and strains from the closely related species Vibrio 
brasiliensis (five strains; Thompson et al., 2003a) and Vibrio hepatarius (one strain; Thompson et al., 2003b) were fingerprinted by rep-PCR as described previously (Cabanillas-Beltran et al., 2006). Briefly, DNA was extracted with a commercial kit (Wizard Genomic DNA purification; Promega) according to the manufacturer's instructions following growth on TSA supplemented with $2.0 \%(\mathrm{w} / \mathrm{v}) \mathrm{NaCl}$. The DNA was adjusted to a concentration of $50 \mathrm{ng} \mathrm{\mu l}^{-1}$ and amplified with the primer $\mathrm{GTG}_{5}$ ( $\left.\mathrm{GTG}_{5}-\mathrm{PCR}\right)$, the amplification products were resolved electrophoretically $(1.2 \% \quad 20 \times 20 \mathrm{~cm}$ agarose gel for $140 \mathrm{~min}$ at $90 \mathrm{~V}$ in $1 \times \mathrm{TAE}$ buffer at room temperature) and the resulting bands were analysed with the GelCompar II software (version 4.5; Applied Maths). A similarity matrix was calculated with the Jaccard coefficient (Kosman \& Leonard, 2005) with a band position tolerance of $0.59 \%$, and a dendrogram was constructed with the Ward algorithm.

The dendrogram showed clear separation between species (Fig. 1) and was also able to identify strains that had identical or very similar ( $>94 \%$ ) GTG $_{5}$-PCR patterns and thus could be considered clones. Because this rep-PCR analysis has been applied to all strains in the CAIM collection (>1800 strains), it allowed us to identify another strain already deposited at the CAIM (CAIM $636=\mathrm{LMG}$ 21563) as genomically related to these snapper strains. This strain was previously identified as Vibrio fortis by FAFLP (Thompson et al., 2003b), although it was not sequenced or compared by DNA hybridization with the type strain of that species. However, the rep-PCR analysis showed

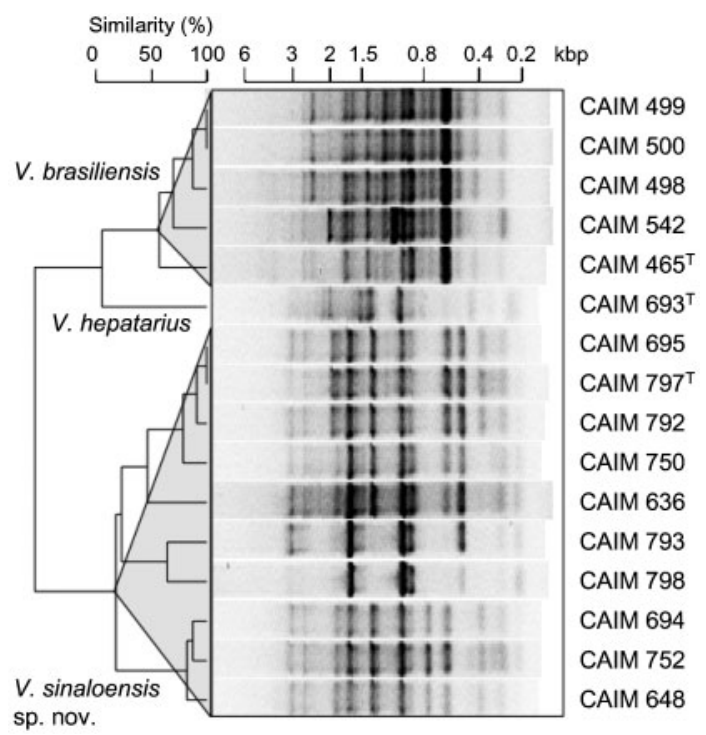

Fig. 1. rep-PCR of the novel snapper strains (Vibrio sinaloensis sp. nov.) compared with strains of $V$. brasiliensis and $V$. hepatarius. The similarity matrix was calculated with the Jaccard coefficient with a position tolerance of $0.59 \%$ and the dendrogram was constructed with the Ward algorithm. similarity values above $44 \%$ (Jaccard, $0.84 \%$ optimization, $0.7 \%$ tolerance) for strain CAIM 636 with the other members of the proposed species represented by the snapper strains and below $40 \%$ with strains belonging to $V$. fortis or $V$. brasiliensis. rep-PCR analysis of the whole database with members of almost all species of the Vibrionaceae (type, reference and environmental strains) using the Jaccard algorithm $(0.59 \%$ tolerance, $0.35 \%$ optimization) has consistently shown a similarity value above $40-42 \%$ to delineate a species, supported by a group separation statistical analysis (jackknife maximum similarities with tie handling assigned to its own group).

The 16S rRNA genes of five strains were sequenced as described previously (Gomez-Gil et al., 2007) and analysed with the MEGA software version 3.1 (Kumar et al., 2001). The 16S rRNA gene sequence of strain CAIM $797^{\mathrm{T}}$ was compared with sequences of the type strains of previously described species (NCBI/Megablast) and the closest species were $V$. brasiliensis $(98.17 \%$ ) and $V$. hepatarius (97.72\%) (Fig. 2). The sequences of the other four strains showed sequence similarity between 97.9 and $98.1 \%$ with $V$. brasiliensis LMG $20546^{\mathrm{T}}$ and between 97.4 and $97.9 \%$ with V. hepatarius LMG $20362^{\mathrm{T}}$. Strain CAIM 636 was also sequenced, showing $99.4 \%$ similarity with CAIM $797^{\mathrm{T}}$, 98.1 and $97.8 \%$ similarity, respectively, with the type strains of $V$. brasiliensis and $V$. hepatarius, and only $96.7 \%$ similarity with $V$. fortis LMG $21557^{\mathrm{T}}$.

DNA-DNA hybridization experiments were done with the hydroxyapatite/microtitre plate method (Ziemke et al., $1998)$ with a hybridization temperature $\left(T_{\mathrm{m}}\right)$ of $50{ }^{\circ} \mathrm{C}$. Results of individual DNA-DNA hybridization determinations of strain CAIM $797^{\mathrm{T}}$ against the type strains of the two closest species ranged between $36.8 \%$ with CAIM $495^{\mathrm{T}}$ and $47.7 \%$ with CAIM $693^{\mathrm{T}}$ (Table 1 ), well below the $70 \%$ threshold established to delineate a species (Wayne et al., 1987). Hybridization values between three strains (CAIM $797^{\mathrm{T}}$, CAIM 695 and CAIM 648) of the proposed novel species showed values above $70 \%$. Reciprocal values with the labelled strain CAIM $495^{\mathrm{T}}$ were in agreement with previous results (Table 1).

Phenotypic characterization was performed on the nine novel strains plus the type strains of $V$. brasiliensis, CAIM $495^{\mathrm{T}}$, and V. hepatarius, CAIM $693^{\mathrm{T}}$, and included the determination of temperature and salinity growth ranges, the ability to hydrolyse several macromolecules extracellularly, the determination of different enzyme activities and the use of 54 substrates as sole carbon and energy sources, as described previously (Macián et al., 2001). In addition, profiles in API 20E strips were also determined as recommended by the manufacturer with the exception that the bacterial suspension was prepared in $2.5 \%$ sterile saline solution. The strains of the novel species showed the basic traits of Vibrio species: they have Gram-negative, oxidase-positive cells that ferment glucose without gas production and require sodium ions for growth. Phenotypic tests were observed that could differentiate 


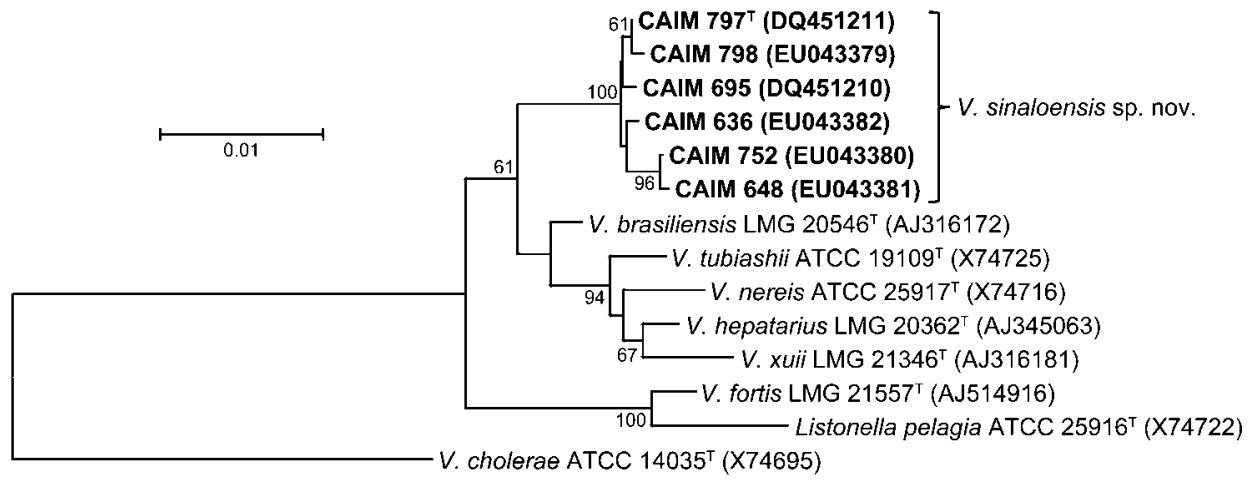

Fig. 2. Phylogenetic tree of six strains of Vibrio sinaloensis sp. nov. and the closest Vibrio species, derived from almostcomplete 16S rRNA gene sequences. The tree topology was obtained by the neighbour-joining method (pairwise deletions, Jukes-Cantor correction). Numbers at nodes indicate percentages of bootstrap support (1000 replicates). Bar, $1 \%$ sequence divergence.

the novel species from phylogenetically related and arginine dihydrolase-positive and lysine and ornithine decarboxylase-negative Vibrio species, as shown in Table 2.

The genotypic and phenotypic data presented here support the proposal of a novel species, for which the name Vibrio sinaloensis sp. nov. is proposed.

\section{Description of Vibrio sinaloensis sp. nov.}

Vibrio sinaloensis (si.na.lo.en'sis. N.L. masc. adj. sinaloensis from the Mexican state of Sinaloa, the source of the first strains).

Gram-negative, curved bacilli that grow as bright-yellow colonies on TCBS agar, are not luminescent and do not swarm on marine agar or on TSA with $2.0 \%(\mathrm{w} / \mathrm{v}) \mathrm{NaCl}$. Growth occurs with $0.35-9 \%(\mathrm{w} / \mathrm{v}) \mathrm{NaCl}$; no growth without $\mathrm{NaCl}$ or with more than $10 \%(\mathrm{w} / \mathrm{v}) \mathrm{NaCl}$. Grows at 15 and $37{ }^{\circ} \mathrm{C}$ but not at $4{ }^{\circ} \mathrm{C}$. Growth at $40{ }^{\circ} \mathrm{C}$ is variable, being negative for strains CAIM 695, CAIM 793 and CAIM 798. Strains are sensitive to the vibriostatic

Table 1. DNA-DNA hybridization results

All analyses were done in duplicate.

\begin{tabular}{|lcc|}
\hline $\begin{array}{l}\text { Source of unlabelled } \\
\text { DNA }\end{array}$ & \multicolumn{2}{c|}{$\begin{array}{c}\text { Hybridization (\%) with } \\
\text { labelled DNA from: }\end{array}$} \\
\cline { 2 - 3 } & $\begin{array}{c}\text { V. sinaloensis } \\
\text { CAIM 797 }\end{array}$ & $\begin{array}{c}\text { V. brasiliensis } \\
\text { CAIM 495 }\end{array}$ \\
\hline V. sinaloensis CAIM 797 & 100 & 44.7 \\
V. sinaloensis CAIM 695 & 78.6 & 46.1 \\
V. sinaloensis CAIM 648 & 91.3 & 66.4 \\
V. brasiliensis CAIM 495 & $47.5^{\mathrm{T}}$ & 100 \\
V. hepatarius CAIM 693 & $49.3^{\mathrm{T}}$ & 61.7 \\
\hline
\end{tabular}

${ }^{*}$ Mean of two hybridization experiments.
Table 2. Phenotypic characteristics that differentiate Vibrio sinaloensis sp. nov. from phylogenetically related and arginine dihydrolase-positive, lysine and ornithine decarboxylase-negative Vibrio species

Taxa: 1, V. sinaloensis sp. nov. (nine strains); 2, V. brasiliensis; 3, V. furnissii; 4, V. hepatarius; 5, V. nereis; 6, V. pacinii; 7, V. splendidus I; 8, V. tubiashii; 9, V. xuii. +, Positive; -, negative; (+), 75-89\% of strains positive; d, doubtful; $v$, variable; ND, no data available. Data for reference species were taken from Alsina \& Blanch (1994) and Macián et al. (2004) ( $V$. furnissii, V. nereis, V. splendidus I, V. tubiashii), Gomez-Gil et al. (2003) ( $V$. pacinii), Thompson et al. (2003a) (V. brasiliensis, V. xuii) and Thompson et al. (2003b) (V. hepatarius). Some additional data were obtained in this study for all reference species with the exception of $V$. pacinii.

\begin{tabular}{|c|c|c|c|c|c|c|c|c|c|}
\hline Test & 1 & 2 & 3 & 4 & 5 & 6 & 7 & 8 & 9 \\
\hline \multicolumn{10}{|l|}{ Growth at/in: } \\
\hline $0.35 \% \mathrm{NaCl}$ & + & + & + & - & - & - & - & - & - \\
\hline $9 \% \mathrm{NaCl}$ & + & - & + & - & + & + & + & + & + \\
\hline $4{ }^{\circ} \mathrm{C}$ & - & - & - & - & $\mathrm{d}$ & + & + & - & - \\
\hline Production of indole & - & + & - & + & + & - & - & + & + \\
\hline \multicolumn{10}{|l|}{ Utilization of: } \\
\hline$\alpha$-Ketoglutaric acid & - & - & - & - & ND & - & + & - & + \\
\hline Acetic acid & $(+)$ & + & $\mathrm{d}$ & + & $\mathrm{d}$ & - & $\mathrm{d}$ & - & + \\
\hline Cellobiose & + & + & - & + & - & + & + & + & + \\
\hline Citrate & + & + & + & + & + & - & + & + & - \\
\hline $\begin{array}{l}\text { D-Galacturonic } \\
\text { acid }\end{array}$ & - & - & + & - & - & - & - & - & - \\
\hline D-Gluconate & + & + & + & + & + & - & $\mathrm{V}$ & + & + \\
\hline D-Mannose & + & + & + & + & - & - & + & + & + \\
\hline L-Aspartic acid & - & + & ND & - & $\mathrm{d}$ & ND & + & - & + \\
\hline Putrescine & - & + & + & - & + & - & - & $\mathrm{d}$ & ND \\
\hline L-Serine & + & + & $\mathrm{ND}$ & - & $\mathrm{d}$ & + & + & - & + \\
\hline L-Alanine & + & + & $\mathrm{ND}$ & - & + & ND & + & - & + \\
\hline $\begin{array}{l}\text { 4-Amino-L-butyric } \\
\text { acid }\end{array}$ & + & + & + & - & + & - & $\mathrm{ND}$ & ND & $\mathrm{ND}$ \\
\hline L-Ornithine & $\mathrm{v}$ & + & - & - & + & - & - & - & + \\
\hline
\end{tabular}


agent $\mathrm{O} / 129$ at 10 and $150 \mu \mathrm{g} \mathrm{ml}^{-1}$. Positive for arginine dihydrolase (Thornley) and tryptophan deaminase (TDA) and negative for lysine and ornithine decarboxylases (Moeller). Ferments glucose without gas formation; positive for ONPG, nitrate reduction, methyl red and gelatinase. Hydrolyses casein, starch, Tween 80, DNA and blood (except CAIM $797^{\mathrm{T}}$ ). Negative for production of indole and $\mathrm{H}_{2} \mathrm{~S}$; negative for citrate utilization, the VogesProskauer reaction and urease. Negative for hydrolysis of alginate, agar and lecithin (except CAIM 793). Utilizes the following substrates as sole sources of carbon: 3-hydroxybutyrate, acetate (except CAIM $797^{\mathrm{T}}$ ), cellobiose (weak reaction for most strains), citrate, D-fructose, D-galactose (except CAIM $797^{\mathrm{T}}$ ), D-glycerate (weak reaction), Dgluconate, D-glucose, D-mannitol (except CAIM $797^{\mathrm{T}}$ and CAIM 792), D-mannose, D-ribose, trehalose, fumarate, glycerol (except CAIM $797^{\mathrm{T}}$ ), glycine, L-glutamic acid, 4amino-L-butyric acid, lactate, L-alanine, L-arginine (weak reaction), L-citrulline (weak reaction), L-histidine (except CAIM $797^{\mathrm{T}}$; weak reaction for CAIM 792), L-serine, Ltyrosine, L-threonine, malate (weak reaction; negative for CAIM 752), maltose, $N$-acetyl-D-glucosamine, pyruvate, propionate, sucrose, succinate and trans-aconitate (weak reaction). Negative for utilization of 2-ketoglutarate, Laspartic acid, amygdalin, betaine, butyrate, D-galacturonate, D-glucuronate, D-sorbitol, D-xylose, lactose, L-arabinose, L-leucine (except CAIM 648, which presents a weak reaction), L-lysine, L-rhamnose, L-sarcosine, myo-inositol and putrescine. Variable results are obtained for melibiose (weak reaction; negative for CAIM $797^{\mathrm{T}}$, CAIM 695 and CAIM 792), salicin (positive for CAIM 750, CAIM 793 and CAIM 798) and L-ornithine (positive for CAIM 695, CAIM 750 and CAIM 792).

The type strain is CAIM $797^{\mathrm{T}}\left(=\mathrm{CECT} 7298^{\mathrm{T}}\right)$. The type strain and the reference strains CAIM 648, CAIM 694, CAIM 695, CAIM 750, CAIM 752, CAIM 792, CAIM 793 and CAIM 798 were isolated from cultured spotted rose snapper, Lutjanus guttatus Steindachner, 1869, in Mazatlán, Sinaloa state, Mexico.

\section{Acknowledgements}

We are grateful to Carmen Bolán-Mejía, Roxana Atondo-Mexía and Beatríz Lacuesta for technical work. This study was financed by FOSEMARNAT project 2004-01-33 (Mexico), the CGL2005-02299/ BOS project (Spanish Ministry of Education and Science) and JACUMAR-Programa Nacional de Cultivo de Lenguado (Spanish Ministry of Agriculture, Fisheries and Food).

\section{References}

Alsina, M. \& Blanch, A. R. (1994). A set of keys for biochemical identification of environmental Vibrio species. J Appl Bacteriol 76, 79-85.
Cabanillas-Beltran, H., Llausas-Magana, E., Romero, R., Espinoza, A., Garcia-Gasca, A., Nishibuchi, M., Ishibashi, M. \& Gomez-Gil, B. (2006). Outbreak of gastroenteritis caused by the pandemic Vibrio parahaemolyticus O3: K6 in Mexico. FEMS Microbiol Lett 265, 76-80.

Euzéby, J. P. (1997). List of bacterial names with standing in nomenclature: a folder available on the internet. Int J Syst Bacteriol 47, 590-592.

Figueras, M. J., Alperi, A., Guarro, J. \& Martinez-Murcia, A. J. (2006). Genotyping of isolates included in the description of a novel species should be mandatory. Int J Syst Evol Microbiol 56, 1183-1184.

Gomez-Gil, B., Thompson, F. L., Thompson, C. C. \& Swings, J. (2003). Vibrio pacinii sp. nov., from cultured aquatic organisms. Int J Syst Evol Microbiol 53, 1569-1573.

Gomez-Gil, B., Fajer-Avila, E. \& Garcia-Vargas, F. (2007). Vibrios of the spotted rose snapper Lutjanus guttatus Steindachner, 1869 from northwestern Mexico. J Appl Microbiol 102, 1518-1526.

Kosman, E. \& Leonard, K. J. (2005). Similarity coefficients for molecular markers in studies of genetic relationships between individuals for haploid, diploid, and polyploid species. Mol Ecol 14, 415-424.

Kumar, S., Tamura, K., Jakobsen, I.-B. \& Nei, M. (2001). MEGA2: molecular evolutionary genetics analysis software. Bioinformatics 17, $1244-1245$.

Lightner, D. V. \& Redman, R. M. (1998). Shrimp diseases and current diagnostic methods. Aquaculture 164, 201-220.

Macián, M. C., Ludwig, W., Aznar, R., Grimont, P. A. D., Schleifer, K. H., Garay, E. \& Pujalte, M. J. (2001). Vibrio lentus sp. nov., isolated from Mediterranean oysters. Int J Syst Evol Microbiol 51, 1449-1456.

Macián, M. C., Garay, E., Grimont, P. A. D. \& Pujalte, M. J. (2004). Vibrio ponticus sp. nov., a neighbour of $V$. fluvialis- $V$. furnissii clade, isolated from gilthead sea bream, mussels and seawater. Syst Appl Microbiol 27, 535-540.

Soto-Rodriguez, S. A., Roque, A., Lizarraga-Partida, M. L., GuerraFlores, A. L. \& Gomez-Gil, B. (2003). Virulence of luminous vibrios to Artemia franciscana nauplii. Dis Aquat Organ 53, 231-240.

Thompson, F. L., Li, Y., Gomez-Gil, B., Thompson, C. C., Hoste, B., Vandemeulebroecke, K., Rupp, G. S., Pereira, A., De Bem, M. M. \& other authors (2003a). Vibrio neptunius sp. nov., Vibrio brasiliensis sp. nov. and Vibrio xuii sp. nov., isolated from the marine aquaculture environment (bivalves, fish, rotifers and shrimps). Int J Syst Evol Microbiol 53, 245-252.

Thompson, F. L., Thompson, C. C., Hoste, B., Vandemeulebroecke, K., Gullian, M. \& Swings, J. (2003b). Vibrio fortis sp. nov. and Vibrio hepatarius sp. nov., isolated from aquatic animals and the marine environment. Int J Syst Evol Microbiol 53, 1495-1501.

Thompson, F. L., lida, T. \& Swings, J. (2004). Biodiversity of vibrios. Microbiol Mol Biol Rev 68, 403-431.

Wayne, L. G., Brenner, D. J., Colwell, R. R., Grimont, P. A. D., Kandler, O., Krichevsky, M. I., Moore, L. H., Moore, W. E. C., Murray, R. G. E. \& other authors (1987). International Committee on Systematic Bacteriology. Report of the ad hoc committee on reconciliation of approaches to bacterial systematics. Int J Syst Bacteriol 37, 463-464.

Ziemke, F., Höfle, M. G., Lalucat, J. \& Rosselló-Mora, R. (1998). Reclassification of Shewanella putrefaciens Owen's genomic group II as Shewanella baltica sp. nov. Int J Syst Bacteriol 48, 179-186. 